Available online on 15.01.2018 at http://ujpr.org
Universal Journal of Pharmaceutical Research
An International Peer Reviewed Journal
Open access to Pharmaceutical research

\title{
ANALYTICAL ENVIRONMENTAL STUDY ON THE POLLUTION EFFECT OF HEAVY METALS IN SOME TYPES OF THE FISH IN YEMEN Mohammed Kassem Othman Al-qadasy ${ }^{1}$ (D), Abdulla Saleh Babaqi ${ }^{1}$, Mukhtar Mohammed Al-Abyadh $^{2}$, Ali Gamal Ahmed Al-kaf ${ }^{3}$ (D) \\ ${ }^{I}$ Department of Chemistry, Faculty of Science, Sana'a University, Sana'a-Yemen. ${ }^{2}$ Department of Chemistry, Faculty of Pharmacy, University of Science and Technology, Aden-Yemen. ${ }^{3}$ Sana'a University-Faculty of pharmacy, Yemen.
}

\section{ABSTRACT}

Objectives: The fish samples were collected from the three different cities of Yemeni coasts. Aden, Al-Hodeidah and AL-Mukalla were chosen for the sample collection. Lethrinusmahsena, Thunnustonggol, Sphyraenajello and Epinephelusareolatus fish samples were considered for the study as they are more common eatable fish among the population.

Methods: The study was carried out in the all three seasons of winter 2011, summer 2012 and winter 2013 in order to check seasonal variation of heavy metal pollution.Total Fish (108 samples of each muscles, liver and gills) were analyzed. The four heavy metals lead, Cadmium, Mercury and arsenic which are considered highly toxic were detected in the samples in the year 2010, 2012 and 2013.

Results: The mean concentration of $\mathrm{Pb}, \mathrm{Cd}, \mathrm{Hg}$ and as in muscle was $0.101 \pm 0.012,0.046 \pm 0.010,0.058 \pm 0.002$ and $0.089 \pm 0.002 \mu \mathrm{g} . \mathrm{g}^{-1}$ dry wt. respectively; whereas in liver was $0.196 \pm 0.033,0.132 \pm 0.020,0.102 \pm 0.007$ and $0.115 \pm 0.0005 \mu \mathrm{g} . \mathrm{g}^{-1} \mathrm{dry}$ wt. respectively; whereas in gill was $0.294 \pm 0.042,0.196 \pm 0.063,0.016 \pm 0.0006$ and $0.034 \pm 0.0005 \mu \mathrm{g} . \mathrm{g}^{-1}$ dry wt. respectively.

The results showed that, the heavy metals concentrations were high in stations AL-Hudaydah and AL-Mukalla and low in station of Aden. Also the heavy metals concentrations were high in Seasons summer and low in Seasons winter.

Conclusion: From the heavy metal concentrations mentioned above we can see that somewhere the concentration is crossing the limits as permissible by the World Health Organization. It suggests a high risk to the health of human being on the consumption of contaminated fish. Therefore it is recommended that the practice of trace element detection should be continued in order to update whether the heavy metal concentration is above or below the permissible limits and if it is above the limit then precautions must be taken to avoid possible consumption of contaminated eatables.

Keywords: Fish samples, heavy metals, seawater, Yemeni coasts.

Article Info: Received 3 November 2017; Revised 1 December; Accepted 29 December, Available online 15 January 2018

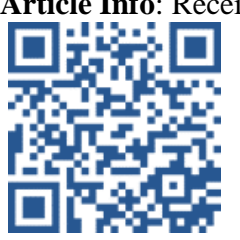

Cite this article-

Al-qadasy MKO, Babaqi AS, Al-Abyadh MM, Al-kaf AGA. Analytical environmental study on the pollution effect of heavy metals in some types of the fish in Yemen. Universal Journal of Pharmaceutical Research 2017; 2(6): 58-72.

DOI: http://doi.org/10.22270/ujpr.v2i6.R11

Address for Correspondence:

Dr. Mohammed Qasem Al-salehi, P.O. Box 11205, Sana'a, Yemen, Mobile: +967-777408835, E-mail: alqadasy64@yahoo.com

\section{INTRODUCTION}

Fishes represent the peak of consumers in the water system. Fishes have ability to collect these metals in concentrations higher than water and sediments because of feed on organic materials in aquatic environments ${ }^{1}$. Fishes have been found to be good indicators of the heavy metal contamination levels in the aquatic systems because they occupy different atrophic levels ${ }^{2}$. According to a previous study ${ }^{2}$ there are two main routes of heavy metals exposure:

1. The primary route of intake of these chemicals in fish species is via gill or transport of dissolved contaminants in water across biological membranes and ionic exchange.
2. The secondary route is through the intestine by food or sediment particles with subsequent transport across the gut.

The food may also be important source for heavy metal accumulation in fish $^{3}$. In aquatic ecosystem, metals are transferred to the fish through food chain that could ultimately affect the health of people consuming this fish. Accumulation of these metals in the bodies of fish affected by different factors such as $\mathrm{pH}$, water hardness and level of pollution in the surrounding water added to the age and physiological situation of fish ${ }^{4}$. Industrial and domestic waste containing heavy metals and hydrocarbon accumulate in aquatic food chains as possible to cause acute and chronic damages in fish 
communities and lead to reduceability to growth and reproduce $^{5}$. Bioaccumulation is the incorporation and retention of metals by organisms from their surrounding environment ${ }^{6}$. A previous study ${ }^{7}$ states that aquatic organisms bioaccumulate trace elements in considerable amounts which may stay in the organism over a long period of time ${ }^{7}$. According to a previous study ${ }^{8}$ metals can have the following effects on fishes: (i) act as mutagenic or genotoxic compounds; (ii) increased metal concentrations can change xenobiotic metabolic pathways and (iii) can affect various metabolic activities such as glycolysis, amino acid- and carbohydrate metabolism ${ }^{8}$.

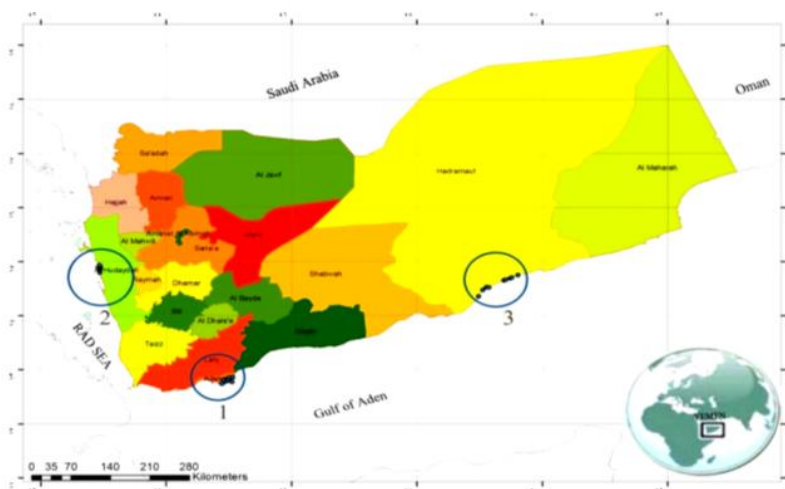

Figure 1: Sampling locations along the Coast of Yemen.

The ability of aquatic organisms to digest heavy metals in the system determines the rate at which heavy metals bioaccumulation in aquatic organisms. Furthermore, the rate of bioaccumulation of heavy metals in aquatic organisms is determined by the concentration of metals in the aquatic system $^{7}$, the feeding habits of the organism and the mode of exposure to heavy metals, which affects the amount of bioaccumulation in different tissues of organisms ${ }^{9}$. Gills and the liver are normally the prime sites for bioaccumulation of heavy metals ${ }^{9}$. Fishes are both situated at the top of the aquatic food chain. Crabs are typically benthic organisms and will give a better indication of the contamination of surface sediment ${ }^{10}$. Various studies have indicated a correlation of heavy metals in tissue of organisms and the size of the organism. Bigger organisms display higher bioaccumulation rates of heavy metals ${ }^{11}$.

\section{MATERIALS AND METHODS}

Description of the study area

The Republic of Yemen lies on the southwestern tip (part) of the Arabian Peninsula bordering Saudi Arabia to the north and Sultanate of Oman to the east. It occupies an area of nearly 555000 square kilometers excluding Al Ruba Al Khali Desert and has a sizeable coast line both to the Red Sea and to the Gulf of Aden/Arabian Sea $(2500 \mathrm{~km})$. Yemen has a large population (approximately 25.956 million in 2013, a high growth rate of approximately $3.7 \%$ per annum ${ }^{12}$.

Fish consumption is apparently increasing at the present time because of the large increases in the price of other alternative protein sources, such as beef, goats and chickens. Yemen's marine environment is characterized by a high level of productivity and fisheries are the second most important source of export revenues in Yemen after petroleum and play an important role in reducing poverty. Aden (on the northwestern side of the Gulf of Aden) AL-Hudaydah (on the southeastern side of the Red Sea) and ALMukalla (on the northeastern side of the Gulf o of Aden) are the main coastal cities (Figure 1) with areas larger than others in Yemen. For these problems and others, we chose this thesis to study the concentrations of heavy metals in the environment of Yemen coast (Aden, Al Hodeidah and Al Mukalla) sites, which is considered as the most important indicator of the extent of the pollution. The study also included estimate of the heavy metals in selected tissues (muscles, liver and gills) of four commercially important fish species, Lethrinusmahsena, Thunnustonggol, Sphyraenajello and Epinephelusareolatus.

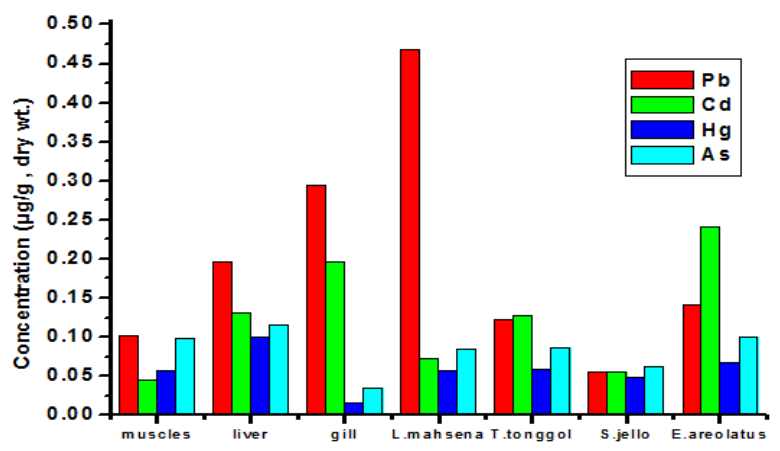

Figure 2: The mean of Concentration $\mu \mathrm{g} / \mathrm{g}$ (dry wt.) for lead, cadmium, mercury and Arsenic in

different organs muscles, livers and gills of the four studied fish species collected from Aden, ALHudaydah and AL-Mukalla station.

\section{Sampling Stations}

The trials were undertaken for the period of seasons: Winter 2011, Summer 2012 and Winter 2013, during which a total of 108 Sample of Muscles Fish,108 Sample of Liver Fish and 108 Sample of Gills Fish were collected and analyzed. Three stations were selected for sampling of large main coastal cities. Samples were collected from three stations. Aden city, overlooking the Gulf of Aden and Al Hodeidah, overlooking the Red Sea and Al Mukalla city, overlooking the Arabian Sea (Table 1).

Table 1: Sampling stations details

\begin{tabular}{lccc}
\hline Station & Longitude (E) & Latitude (N) & Description \\
\hline Aden city & $45^{\circ} 04^{\prime} 88^{\prime \prime} \mathrm{E}$ & $12^{\circ} 77^{\prime} 53^{\prime \prime} \mathrm{N}$ & overlooking the Gulf of Aden \\
AL-Hudaydahcity & $42^{\circ} 94^{\prime} 05^{\prime \prime} \mathrm{E}$ & $14^{\circ} 91^{\prime} 35^{\prime \prime} \mathrm{N}$ & overlooking the Red Sea \\
AL-Mukalla city & $49^{\circ} 10^{\prime} 67^{\prime \prime} \mathrm{E}$ & $14^{\circ} 52^{\prime} 87^{\prime \prime} \mathrm{N}$ & overlooking the Arabian Sea \\
\hline
\end{tabular}




\section{Fish Species}

To assess the health of the aquatic environment, aquatic organisms are usually used as biological monitors because they tend to accumulate pollutants from their environment and reflect the combined effects over a period of time ${ }^{13}$. Study species are often chosen depending on the monitoring purpose and the information available on environmental contamination. If the information on pollutants is available, certain indicators could be chosen for a optimum use or cost. In this study, the risk of trace metal exposure to humans consuming fish from the Yemen seas was an important question therefore fish were chosen for the study. In order to meet the requirements of monitoring species $^{14}$. Table 2 shows the fish species used in the study. This study examined trace metals in the muscle and the different fish tissues (liver and gill) of fish. Muscle was been chosen because it is the edible part and the result from measuring metals in muscle is used to assess the risk of trace metal exposure to humans consuming fish liver and Gill, however, was chosen because the metal bioaccumulation in liver is relative higher than any other tissues in biota, so it can be a good environmental indicator of trace metal contamination ${ }^{15}$.

Table 2: Target species for fish from three sites.

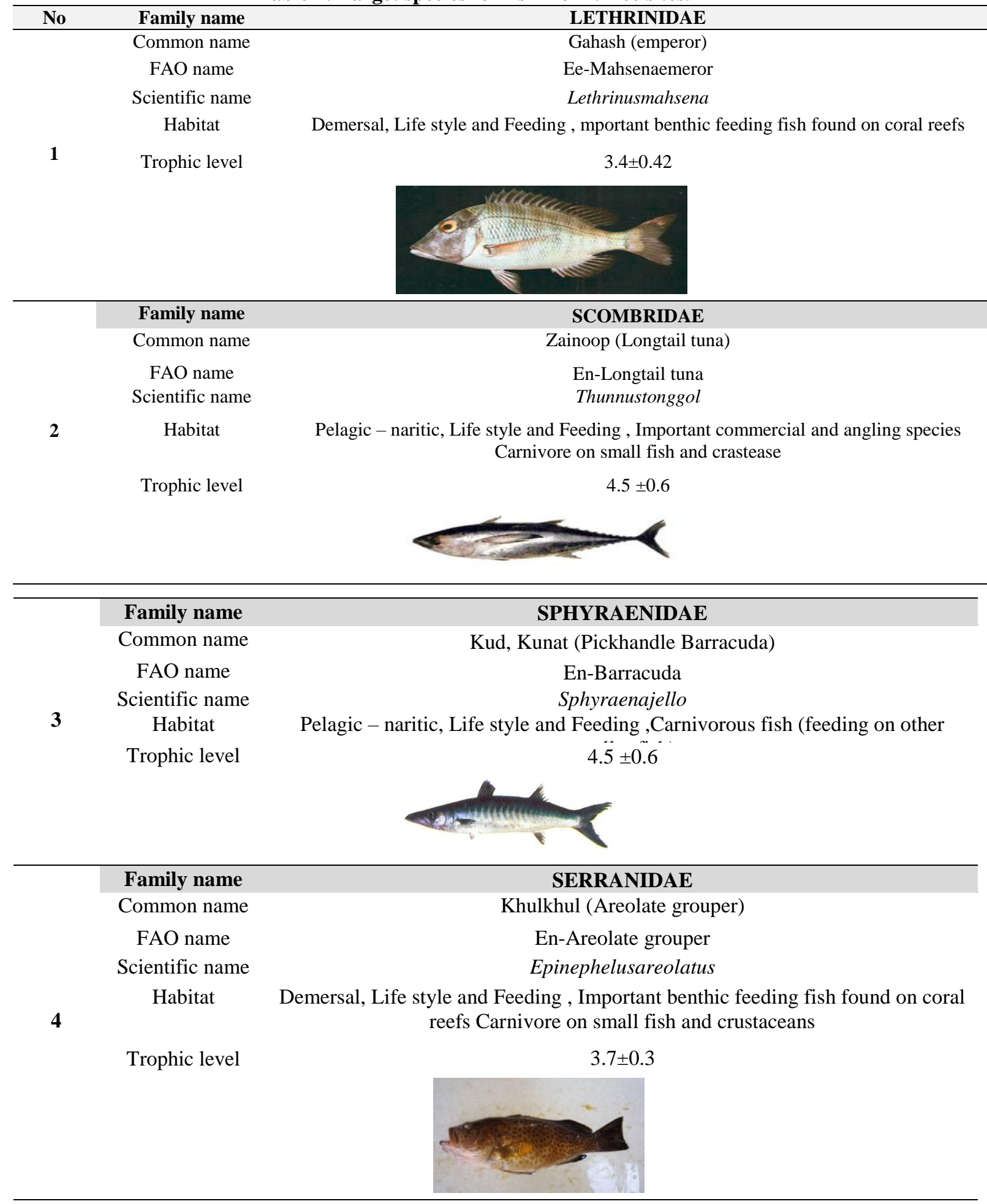


Table 3: The mean weight and length of fish collected during the seasons from Aden, AL-Hudaydah and ALMukalla Stations, Yemen coast.

\begin{tabular}{|c|c|c|c|c|}
\hline Site & Species & Size & $\begin{array}{l}\text { Weight (g) } \\
\text { Mean } \pm \text { Stdd }\end{array}$ & $\begin{array}{c}\text { Length }(\mathrm{cm}) \\
\text { Mean } \pm \text { Std.M }\end{array}$ \\
\hline \multirow{12}{*}{ Aden } & \multirow{3}{*}{ Lethrinusmahsena } & Large & $445.89 \pm 14.31$ & $29.32 \pm 1.09$ \\
\hline & & Medium & $358.83 \pm 54.32$ & $26.24 \pm 1.61$ \\
\hline & & Small & $252.52 \pm 24.21$ & $24.25 \pm 1.15$ \\
\hline & \multirow{3}{*}{ Thunnustonggol } & Large & $3513.05 \pm 411.4$ & $73.33 \pm 2.04$ \\
\hline & & Medium & $2652.85 \pm 214.79$ & $60.4 \pm 1.65$ \\
\hline & & Small & $1860.49 \pm 78.34$ & $52.93 \pm 1.93$ \\
\hline & \multirow[t]{4}{*}{ Sphyraenajello } & Large & $890.56 \pm 160.38$ & $52.73 \pm 1.6$ \\
\hline & & Medium & $741.84 \pm 30.8$ & $48.37 \pm 0.7$ \\
\hline & & Small & $587.24 \pm 30.31$ & $44.5 \pm 0.79$ \\
\hline & & Large & $798.95 \pm 49.43$ & $40.4 \pm 0.91$ \\
\hline & \multirow[t]{3}{*}{ Epinephelusareolatus } & Medium & $444.11 \pm 17.44$ & $31.53 \pm 2.06$ \\
\hline & & Small & $242.24 \pm 47.95$ & $23.93 \pm 1.47$ \\
\hline \multirow{12}{*}{ Al Hudaydah } & & Large & $1085.77 \pm 75.04$ & $37.07 \pm 0.82$ \\
\hline & \multirow[t]{3}{*}{ Lethrinusmahsena } & Medium & $746.49 \pm 139.89$ & $32.63 \pm 2.08$ \\
\hline & & Small & $238.13 \pm 60.67$ & $23.27 \pm 1.78$ \\
\hline & & Large & $3416.47 \pm 421.55$ & $64.47 \pm 2.84$ \\
\hline & \multirow[t]{2}{*}{ Thunnustonggol } & Medium & $2338.1 \pm 97.98$ & $56.5 \pm 0.85$ \\
\hline & & Small & $1878.68 \pm 94.29$ & $52.2 \pm 0.96$ \\
\hline & \multirow{4}{*}{ Sphyraenajello } & Large & $1156.43 \pm 78.07$ & $57.17 \pm 1.21$ \\
\hline & & Medium & $694.31 \pm 79.85$ & $47.5 \pm 1.42$ \\
\hline & & Small & $484.48 \pm 24.65$ & $42.37 \pm 1.28$ \\
\hline & & Large & $911.37 \pm 66.14$ & $39.13 \pm 0.7$ \\
\hline & \multirow[t]{2}{*}{ Epinephelusareolatus } & Medium & $678.33 \pm 51.94$ & $35.5 \pm 0.79$ \\
\hline & & Small & $374 \pm 32.24$ & $29.17 \pm 0.98$ \\
\hline \multirow{12}{*}{ Al Mukalla } & \multirow{3}{*}{ Lethrinusmahsena } & Large & $746.8 \pm 50.18$ & $34.1 \pm 1.53$ \\
\hline & & Medium & $544.82 \pm 51.53$ & $30.77 \pm 0.97$ \\
\hline & & Small & $359.78 \pm 37.32$ & $26.43 \pm 1.09$ \\
\hline & \multirow{3}{*}{ Thunnustonggol } & Large & $2893.21 \pm 147.23$ & $62.37 \pm 1.05$ \\
\hline & & Medium & $2268.93 \pm 218.43$ & $57.57 \pm 1.82$ \\
\hline & & Small & $1614.56 \pm 107.72$ & $51.53 \pm 1.13$ \\
\hline & \multirow{3}{*}{ Sphyraenajello } & Large & $1037.37 \pm 175.26$ & $55.37 \pm 3.19$ \\
\hline & & Medium & $625.67 \pm 93.35$ & $46.57 \pm 2.34$ \\
\hline & & Small & $454.82 \pm 34.13$ & $41.8 \pm 1.06$ \\
\hline & \multirow{3}{*}{ Epinephelusareolatus } & Large & $857.36 \pm 51.75$ & $41.37 \pm 1.18$ \\
\hline & & Medium & $353.8 \pm 81.85$ & $35.33 \pm 1.92$ \\
\hline & & Small & $187.48 \pm 53.95$ & $24.13 \pm 2.4$ \\
\hline
\end{tabular}

All collected organisms were weighed (wet wt.) and measured (total weight for fish and length) in Table 3 upon return to the laboratory. Characteristics (number of individuals, length and weight) of each of the 4 species collected are given in Table 3 . This table also indicates the trophic level (i.e. grazer/ scavenger, predator of invertebrates, predator of invertebrates and small fish, predator of small fish) and the water-column 
distribution (benthic, nectobenthic and neritic) for every species.

While making a selection for the fish species to be taken for the present study, following criteria's were taken into consideration:

1. Edible status

2. Presence at all the selected sites

3. Popularity with the people of Yemen

Based on these criterias, four widely consumed fish species were selected viz. Lethrinusmahsena, Thunnustonggol, Sphyraenajello and Epinephelusareolatus. Their common names in Yemen are Gahash, Zainoop, Kud and Khulkhul respectively.

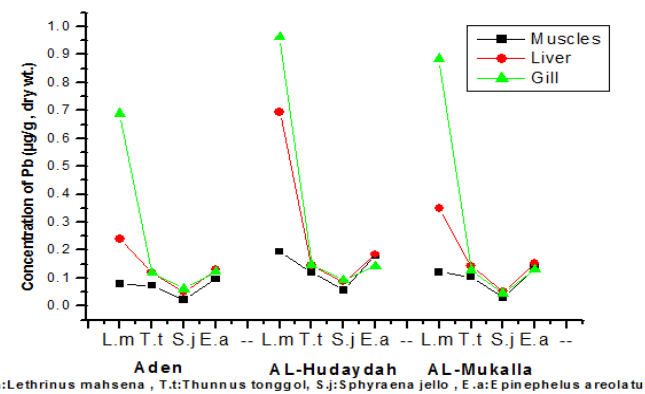

Figure 3: The mean of Concentration $\mu g / g$ (dry wt.) for Lead in different organs muscles, livers and gills of the four studied fish species collected from Aden, AL-Hudaydah and AL-Mukalla station.

Fish Sampling and Analysis

Fish Sampling

A total of 324 specimens of four commercially important fish species, Lethrinusmahsena, Thunnustonggol, Sphyraenajello and Epinephelusareola were collected seasons with the help of local fishermen from Aden, Al Hodeidah and Al Mukalla during the study period of seasons (winter 2011, summer 2012 and winter 2013). Samples were placed immediately in poly-ethylene bags, put into ice box, after that brought to the laboratory at the faculty of Environmental Sciences and Marine Biology, Hadramout University. The total length and the body wet weight of each specimen were measured to the nearest centimeter and gram respectively ${ }^{14}$. After measurements, fish samples were washed with deionized water, sealed in polyethylene bags and kept in a freezer at $-20^{\circ} \mathrm{C}$ until chemical analysis ${ }^{14}$.

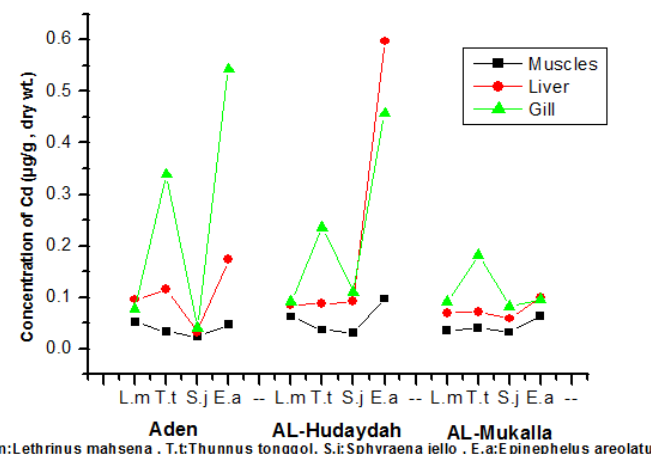

Figure 4: The mean of Concentration $\mu g / g$ (dry wt.) for Cadmium in different organs muscles, livers and gills of the four studied fish species collected from

Aden, AL-Hudaydah and AL-Mukalla station.

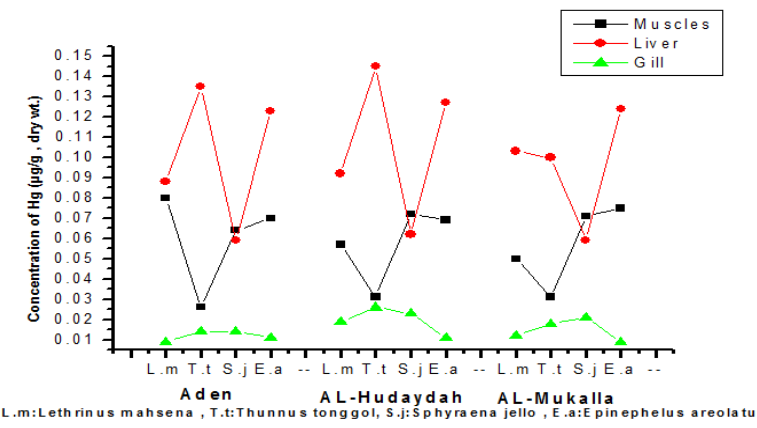

Figure 5: The mean of Concentration $\mu \mathrm{g} / \mathrm{g}$ (dry wt.) for Mercury in different organs muscles, livers and gills of the four studied fish species collected from

Aden, AL-Hudaydah and AL-Mukalla station.

\section{Fish tissue digestion and analysis}

Fish tissues were dried in oven at $\left(80^{\circ} \mathrm{C}\right)$ until sample is at a constant weight. About $0.500 \mathrm{~g}$ of dry tissue sample (muscles, liver or gills) was accurately weighed and digested with $7 \mathrm{ml}$ of concentrated nitric acid $\left(\mathrm{HNO}_{3} 65 \%\right)$ and $1 \mathrm{ml}$ of hydrogen peroxide $\left(\mathrm{H}_{2} \mathrm{O}_{2}\right.$ $30 \%$ ). Milestone Start Microwave Digestion Lab station with internal Temperature sensor and 260 terminal teach screen With HPR1000/10S High Pressure Segmented rotor (Application Note HPR-FO07) and AOAC Official Method ${ }^{16} 999.10$ and 974.14

Microwave Program 2 Steps (1)15.00 Min

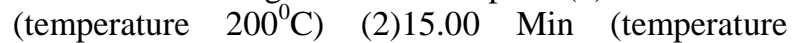
$200^{\circ} \mathrm{C}$ ). After Finish left vessels $20 \mathrm{~min}$ until reach the room temperature, then the digested portion was diluted to a final volume of $50 \mathrm{ml}$ using deionized water, before proceeding US EPA Method ${ }^{17} 3052$.

$\mathrm{Pb}$ Analyzed without Further Treatment, $\mathrm{Cd}$ diluted with Factor $2, \mathrm{Hg}$ and As Diluted with Factor 100 .

The Certified Reference Material DORM-2 Analyzed for $\mathrm{ForPb}, \mathrm{Cd}, \mathrm{Hg}$ and $\mathrm{As}$ Content.

i. Lead and Cadmium analysis in fish tissues by GFAAS

Graphite furnace atomic absorption spectrometry (Model 220 GF), U.S.A Made, were used for analysis of $\mathrm{Cd}$ and $\mathrm{Pb}$ in fish tissue samples, Perfect for AOAC Official Method ${ }^{16} 999.10$.

ii. Mercury and Arsenic analysis in fish tissues by Hydride analyzer

Cold Vapor Hg Analyzer (Buck Model 410), U.S.A Made, were used for analysis of $\mathrm{Hg}$ in fish tissue samples, Perfect for AOAC Official Method ${ }^{16}$ 974.14 . Arsenic Hydride Analyzer (Buck Model 411), U.S.A Made, were used for analysis of As in fish tissue samples, Perfect for EPA method ${ }^{18}$ 206.3. Recovery studies were performed in order to establish the accuracy of the method. Recovery of the metals was determined by spiking one sample with increasing amounts of metal standard solution. The spiked samples were then taken through the same digestion procedure (as all other samples) and analyzed for heavy metal concentrations. To assess the precision of the overall procedure, the samples were divided in batch of eight and for each batch; three replicate analyses of one of the samples were conducted. 
Table 4: The mean of Concentration $\mu \mathrm{g} / \mathrm{g}$ (dry wt.) for lead, cadmium, mercury and Arsenic in different organs muscles, livers and gills of the four studied fish species collected from Aden, AL-Hudaydah and ALMukalla station.

\begin{tabular}{|c|c|c|c|c|c|}
\hline \multirow{2}{*}{ Species } & \multirow{2}{*}{$\begin{array}{c}\text { Metal } \\
\text { ion }\end{array}$} & \multicolumn{3}{|c|}{ Organ } & \multirow{2}{*}{$\begin{array}{c}\text { Total } \\
\text { mean } \pm \text { SD }\end{array}$} \\
\hline & & Muscles & Liver & Gill & \\
\hline \multirow{4}{*}{ Lethrinusmahsena } & $\mathrm{Pb}$ & $0.132 \pm 0.048$ & $0.428 \pm 0.031$ & $0.845 \pm 0.009$ & $0.468 \pm 0.358$ \\
\hline & $\mathrm{Cd}$ & $0.049 \pm 0.016$ & $0.084 \pm 0.007$ & $0.087 \pm 0.009$ & $0.073 \pm 0.021$ \\
\hline & $\mathrm{Hg}$ & $0.062 \pm 0.0005$ & $0.094 \pm 0.001$ & $0.014 \pm 0.002$ & $0.057 \pm 0.040$ \\
\hline & As & $0.106 \pm 0.007$ & $0.121 \pm 0.007$ & $0.026 \pm 0.006$ & $0.084 \pm 0.051$ \\
\hline \multirow{4}{*}{ Thunnustonggol } & $\mathrm{Pb}$ & $0.100 \pm 0.018$ & $0.137 \pm 0.022$ & $0.133 \pm 0.014$ & $0.123 \pm 0.020$ \\
\hline & $\mathrm{Cd}$ & $0.037 \pm 0.008$ & $0.092 \pm 0.031$ & $0.253 \pm 0.142$ & $0.127 \pm 0.112$ \\
\hline & $\mathrm{Hg}$ & $0.030 \pm 0.006$ & $0.127 \pm 0.026$ & $0.020 \pm 0.005$ & $0.059 \pm 0.059$ \\
\hline & As & $0.071 \pm 0.028$ & $0.147 \pm 0.032$ & $0.041 \pm 0.017$ & $0.086 \pm 0.055$ \\
\hline \multirow{4}{*}{ Sphyraenajello } & $\mathrm{Pb}$ & $0.037 \pm 0.009$ & $0.062 \pm 0.019$ & $0.067 \pm 0.016$ & $0.055 \pm 0.016$ \\
\hline & $\mathrm{Cd}$ & $0.029 \pm 0.010$ & $0.061 \pm 0.013$ & $0.077 \pm 0.008$ & $0.056 \pm 0.024$ \\
\hline & $\mathrm{Hg}$ & $0.069 \pm 0.011$ & $0.060 \pm 0.016$ & $0.019 \pm 0.003$ & $0.049 \pm 0.027$ \\
\hline & As & $0.090 \pm 0.013$ & $0.070 \pm 0.017$ & $0.025 \pm 0.005$ & $0.062 \pm 0.033$ \\
\hline \multirow{4}{*}{ Epinephelusareolat } & $\mathrm{Pb}$ & $0.137 \pm 0.014$ & $0.156 \pm 0.015$ & $0.133 \pm 0.011$ & $0.142 \pm 0.012$ \\
\hline & $\mathrm{Cd}$ & $0.069 \pm 0.021$ & $0.289 \pm 0.020$ & $0.365 \pm 0.032$ & $0.241 \pm 0.154$ \\
\hline & $\mathrm{Hg}$ & $0.071 \pm 0.012$ & $0.124 \pm 0.017$ & $0.010 \pm 0.001$ & $0.068 \pm 0.057$ \\
\hline & As & $0.132 \pm 0.048$ & $0.123 \pm 0.010$ & $0.045 \pm 0.003$ & $0.100 \pm 0.048$ \\
\hline \multirow[t]{4}{*}{ Total mean \pm SD } & $\mathrm{Pb}$ & $0.102 \pm 0.046$ & $0.196 \pm 0.160$ & $0.294 \pm 0.368$ & $0.197 \pm 0.096$ \\
\hline & $\mathrm{Cd}$ & $0.046 \pm 0.017$ & $0.132 \pm 0.106$ & $0.196 \pm 0.139$ & $0.124 \pm 0.075$ \\
\hline & $\mathrm{Hg}$ & $0.058 \pm 0.019$ & $0.101 \pm 0.031$ & $0.016 \pm 0.005$ & $0.058 \pm 0.043$ \\
\hline & As & $0.099 \pm 0.026$ & $0.115 \pm 0.032$ & $0.034 \pm 0.010$ & $0.083 \pm 0.043$ \\
\hline
\end{tabular}

Analyses of all sample digests were performed in duplicate by the instrument. Certified Reference Material (CRM), DogFish (DORM-2) from the National Research Council, Canada was also included in quintuplicate.

Statistical analysis

All heavy metals data (lead, cadmium and mercury) were analyzed and tested for differences between group means of stations and seasons for significance ( $\mathrm{P} \leq 0.05)$ using the analysis of variance one way ANOVA and two ways ANOVA technique. Also, group means of environmental factors were analyzed by one way ANOVA technique. All statistical analysis was performed using the Origin 9 and SPSS software packages, version 17.0.

\section{RESULTS}

Heavy Metals in different organs

Lead

The average concentration of Lead throughout all the three Sizes in Muscles Fish was $0.091 \mu \mathrm{g} / \mathrm{g}$ dry wt (At Small) to $0.184 \mu \mathrm{g} / \mathrm{g}$ dry wt (At large) for L. mahsena and from $0.080 \mu \mathrm{g} / \mathrm{g}$ dry wt (At Small ) to $0.116 \mu \mathrm{g} / \mathrm{g}$ dry wt (At large) for T. tonggol. and from $0.029 \mu \mathrm{g} / \mathrm{g}$ 
dry wt (At Small) to $0.046 \mu \mathrm{g} / \mathrm{g}$ dry wt (At large) for $S$. jello and from $0.125 \mu \mathrm{g} / \mathrm{g}$ dry wt (At Small) to $0.152 \mu \mathrm{g} / \mathrm{g}$ dry wt (At large) for E. areolatus.

The average concentration of Lead throughout all the three sizes in liver fish was $0.394 \mu \mathrm{g} / \mathrm{g}$ dry wt (At Small) to $0.456 \mu \mathrm{g} / \mathrm{g}$ dry wt (At large) for $L$. mahsenaand from $0.115 \mu \mathrm{g} / \mathrm{g}$ dry wt (At Small) to $0.158 \mu \mathrm{g} / \mathrm{g}$ dry wt (At large) for T. tonggol. and from $0.043 \mu \mathrm{g} / \mathrm{g}$ dry wt (At Small) to $0.081 \mu \mathrm{g} / \mathrm{g}$ dry wt (At large) for $S$. jelloand from $0.144 \mu \mathrm{g} / \mathrm{g}$ dry wt (At Small) to $0.174 \mu \mathrm{g} / \mathrm{g}$ dry wt (At large) for E. areolatus.

Table 5: The covariance analysis between mean concentration of $\mathrm{Pb}(\mu \mathrm{g} / \mathrm{g})$ among in some types of fishes in Yemeni seas and different variables.

\begin{tabular}{|c|c|c|c|c|c|c|}
\hline Source & $\begin{array}{l}\text { Type III Sum of } \\
\text { Squares }\end{array}$ & df & $\begin{array}{c}\text { Mean } \\
\text { Square }\end{array}$ & $\mathbf{F}$ & p & $\begin{array}{c}\text { Partial Eta } \\
\text { Squared }\left(\mathbf{R}^{2}\right)\end{array}$ \\
\hline Corrected Model & $11.090 \mathrm{a}$ & 11 & 1.008 & 42.000 & 0.000 & 0.597 \\
\hline Intercept & 0.005 & 1 & 0.005 & 0.202 & 0.653 & 0.001 \\
\hline Seasons & 0.121 & 2 & 0.060 & 2.513 & 0.083 & 0.016 \\
\hline Tissue & 2.013 & 2 & 1.007 & 41.940 & 0.000 & 0.212 \\
\hline Species & 4.315 & 3 & 1.438 & 59.921 & 0.000 & 0.366 \\
\hline Site & 0.515 & 2 & 0.257 & 10.727 & 0.000 & 0.064 \\
\hline Weight (Kg) & 0.000 & 1 & 0.000 & 0.016 & 0.899 & 0.000 \\
\hline Length (M) & 0.035 & 1 & 0.035 & 1.474 & 0.226 & 0.005 \\
\hline Error & 7.489 & 312 & 0.024 & & & \\
\hline Total & 31.180 & 324 & & & & \\
\hline Corrected Total & 18.579 & 323 & & & & \\
\hline
\end{tabular}

Table 6: The mean concentration of $\mathrm{Pb}(\mu \mathrm{g} / \mathrm{g})$ among the areas, type and the tissues of the fish.

\begin{tabular}{llccc}
\hline (I) Site & (J) Site & $\begin{array}{c}\text { Mean Difference } \\
(\mathbf{I}-\mathbf{J})\end{array}$ & Std Error & $\mathbf{P}^{\mathbf{b}}$ \\
\hline Al Mukalla & Aden & $-0.048^{*}$ & 0.017 & 0.012 \\
& Al Hudaydah & $-0.075^{*}$ & 0.017 & 0.008 \\
(I) Species & (J) Species & & & \\
Lethrinusmahsena & Thunnustonggol & $0.446^{*}$ & 0.051 & 0.000 \\
& Sphyraenajello & $0.484^{*}$ & 0.057 & 0.000 \\
& E. areolatus & $0.342^{*}$ & 0.027 & 0.000 \\
E. areolatus & Sphyraenajello & $0.143^{*}$ & 0.046 & 0.013 \\
(I) Tissue & (J) Tissue & & & \\
Muscles & Liver & $-0.094^{*}$ & 0.021 & 0.000 \\
& Gill & $-0.193^{*}$ & 0.021 & 0.000 \\
Liver & Gill & $-0.099^{*}$ & 0.021 & 0.000 \\
\hline
\end{tabular}

Based on estimated marginal means*. The mean difference is significant at the 0.05 level. b. Adjustment for multiple comparisons: Bonferroni.

The average concentration of Lead throughout all the three sizes in Gill Fish was $0.835 \mu \mathrm{g} / \mathrm{g}$ dry wt (At Small) to $0.853 \mu \mathrm{g} / \mathrm{g}$ dry wt (At large) for L. mahsena and from $0.120 \mu \mathrm{g} / \mathrm{g}$ dry wt (At Small ) to $0.148 \mu \mathrm{g} / \mathrm{g}$ dry wt (At large) for T. tonggol. and from $0.052 \mu \mathrm{g} / \mathrm{g}$ dry wt (At Small) to $0.084 \mu \mathrm{g} / \mathrm{g}$ dry wt (At large) for $S$. jello and from $0.121 \mu \mathrm{g} / \mathrm{g}$ dry wt (At Small) to 0.144 $\mu \mathrm{g} / \mathrm{g}$ dry wt (At large) for E. areolatus. The high concentration of $\mathrm{Pb}(0.845 \pm 0.009 \mu \mathrm{g} / \mathrm{g}$ dry wt. $)$ was found in the Gill tissue of L. mahsena (Table 4), while in the lowest concentration of lead level $(0.037 \pm 0.009 \mu \mathrm{g} / \mathrm{g}$ dry wt.) was detected in the muscle tissue of $S$. jello (Table 4). The mean concentration of $\mathrm{Pb}$ in the muscles, livers and gills of the four studied fish species varied from a minimum of $0.037 \pm 0.009$, $0.062 \pm 0.019$ and $0.067 \pm 0.016$ in $S$. jello, to a maximum value of $0.137 \pm 0.014 ; 0.428 \pm 0.031$ and $0.845 \pm 0.009$ in E. areolatus , L. mahsena (Table 4), (Figure 2). Table 5 shows the covariance analysis between mean concentration of $\mathrm{Pb}$ among in some types of fishes in Yemeni seas and different variables. These different variables include; tissue, type and area of the fish. After included the weight and length factors to show the related impact in the change of concentration of $\mathrm{Pb}$ to the three periods of time, the covariance analysis was not statistically significant in which the $(p<0.01)$. The mean concentration of $\mathrm{Pb}$ to the species of fish, among the tissues of the fish and among three different areas of fishing were also statistically significant with the $\mathrm{p}$ value are similar $(p<0.01)$, where the impact of these differences in concentration ratio of $\mathrm{Pb}$ were $(37 \%, 21 \%$ and $6 \%)$ respectively.

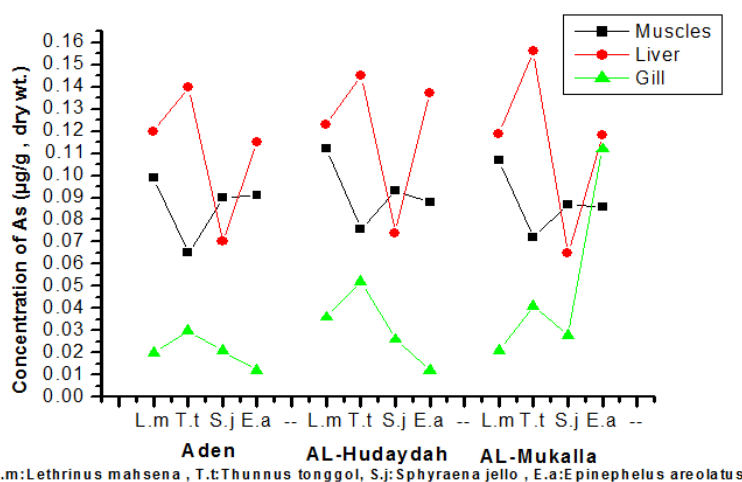

Figure 6: The mean of Concentration $\mu \mathrm{g} / \mathrm{g}(\mathrm{dry} \mathbf{w t}$ ) for Arsenic in different organs muscles, livers and gills of the four studied fish species collected from Aden, AL-Hudaydah and AL-Mukalla station. 
Table 6 shows the mean concentration of $\mathrm{Pb}$ among the areas, type and the tissues of the fish. The concentration of $\mathrm{Pb}$ were concentrated at Between $\mathrm{Al}$ Mukalla and Aden, Al Hudaydah in which the mean concentration of $\mathrm{Pb}$ among fishes were (0.048 and 0.075) Towards Aden, Al-Hudaydah respectively, these results were statistically significant $(p<0.01)$. The differences in the mean concentration of $\mathrm{Pb}$ among the different types of the fishes were found between L. smahsen and three other types and the mean concentration was in $T$. tonggol(0.446), S. jello (0.484) and E. areolatus $(0.342)$.

Table 7: The covariance analysis between mean concentration of $\mathrm{Cd}(\mu \mathrm{g} / \mathrm{g})$ among in some types of fishes in Yemeni seas and different variables.

\begin{tabular}{lcccccc}
\hline Source & $\begin{array}{c}\text { Type III Sum of } \\
\text { Squares }\end{array}$ & df & $\begin{array}{c}\text { Mean } \\
\text { Square }\end{array}$ & F & P & $\begin{array}{c}\text { Partial Eta } \\
\text { Squared }\end{array}$ \\
\hline Corrected Model & $3.789^{\mathrm{a}}$ & 11 & 0.344 & 23.659 & 0.000 & 0.455 \\
Intercept & 0.022 & 1 & 0.022 & 1.530 & 0.217 & 0.005 \\
Seasons & 0.192 & 2 & 0.096 & 6.599 & 0.002 & 0.041 \\
Tissue & 1.212 & 2 & 0.606 & 41.640 & 0.000 & 0.211 \\
Species & 1.705 & 3 & 0.568 & 39.048 & 0.000 & 0.273 \\
Site & 0.289 & 2 & 0.144 & 9.922 & 0.000 & 0.060 \\
Wight (Kg) & 0.084 & 1 & 0.084 & 5.745 & 0.017 & 0.018 \\
Length (M) & 0.004 & 1 & 0.004 & 0.301 & 0.584 & 0.001 \\
Error & 4.542 & 312 & 0.015 & & & \\
Total & 13.350 & 324 & & & & \\
Corrected Total & 8.331 & 323 & & & &
\end{tabular}

Table 8: The mean concentration of $\mathrm{Cd}(\mu \mathrm{g} / \mathrm{g})$ among the areas, type and the tissues of the fish.

\begin{tabular}{lcccc}
\hline (I) Site & $(\mathbf{J})$ Site & $\begin{array}{c}\text { Mean Difference } \\
(\mathbf{I}-\mathbf{J})\end{array}$ & Std. Error & $\mathbf{P}^{\mathbf{b}}$ \\
\hline Al Mukalla & Aden & $-0.048^{*}$ & 0.017 & 0.012 \\
& Al Hudaydah & $-0.075^{*}$ & 0.017 & 0.000 \\
(I) Species & (J) Species & & & 0.000 \\
E. areolatus & Lethrinusmahsena & $0.173^{*}$ & 0.021 & 0.000 \\
& Thunnustonggol & $0.246^{*}$ & 0.038 & 0.000 \\
Sphyraenajello & (J) Tissue & $0.182^{*}$ & 0.036 & 0.000 \\
Muscles & Liver & $-0.086^{*}$ & 0.016 & 0.000 \\
& Gill & $-0.149^{*}$ & 0.016 & 0.000 \\
Liver & Gill & $-0.064^{*}$ & 0.016 & 0.006 \\
(I) Time & (J) Time & & & 0.016 \\
Phase 2011 & Phase 2012 & $-0.052^{*}$ & 0.017 & 0.005 \\
\hline
\end{tabular}

Based on estimated marginal means *. The mean difference is significant at the .05 level. $\quad$ b. Adjustment for multiple comparisons: Bonferroni

The direction of the type of fish L. mahsena, these difference was statistically significant $(p<0.01)$. Also found between E. areolatus and S. jello (0.143).The direction of the type of fish E. areolatus, this difference was statistically significant $(\mathrm{p}<0.05)$. According the concentration of $\mathrm{Pb}$ among the tissues of the fish was found among the muscles and liver (0.094), muscles and gill (0.193) The direction of the average lead concentration in the liver and Gill respectively, and liver and gill, (0.099) The direction of the average lead concentration in the Gill and these results were statistically significant $(p<0.01)$.

\section{Cadmium}

The average concentration of Cadmium throughout all the three Sizes in Muscles Fish was $0.091 \mu \mathrm{g} / \mathrm{g}$ dry wt (At Small) to $0.184 \mu \mathrm{g} / \mathrm{g}$ dry wt (At large) for $L$. mahsenaand from $0.029 \mu \mathrm{g} / \mathrm{g}$ dry wt (At Small ) to $0.046 \mu \mathrm{g} / \mathrm{g}$ dry wt (At large) for T. tonggol. and from $0.020 \mu \mathrm{g} / \mathrm{g}$ dry wt (At Small) to $0.040 \mu \mathrm{g} / \mathrm{g}$ dry wt (At large) for $S$. jello and from $0.047 \mu \mathrm{g} / \mathrm{g}$ dry wt (At Small) to $0.088 \mu \mathrm{g} / \mathrm{g}$ dry wt (At large) for E. areolatus. The average concentration of Cadmium throughout all the three Sizes in Liver Fish was $0.079 \mu \mathrm{g} / \mathrm{g}$ dry wt (At Small) to $0.092 \mu \mathrm{g} / \mathrm{g}$ dry wt (At large) for L. mahsena and from $0.065 \mu \mathrm{g} / \mathrm{g}$ dry wt (At Small ) to $0.126 \mu \mathrm{g} / \mathrm{g}$ dry wt (At large) for T. tonggol. and from $0.047 \mu \mathrm{g} / \mathrm{g}$ dry wt (At Medium) to $0.073 \mu \mathrm{g} / \mathrm{g}$ dry wt (At large) for $S$. jelloand from $0.277 \mu \mathrm{g} / \mathrm{g}$ dry wt (At Medium) to $0.312 \mu \mathrm{g} / \mathrm{g}$ dry wt (At large) for $E$. areolatus. The average concentration of Cadmium throughout all the three Sizes in Liver Fish was $0.079 \mu \mathrm{g} / \mathrm{g}$ dry wt (at small) to $0.092 \mu \mathrm{g} / \mathrm{g}$ dry wt (At large) for $L$. mahsenaand from $0.065 \mu \mathrm{g} / \mathrm{g}$ dry wt (At Small) to $0.126 \mu \mathrm{g} / \mathrm{g}$ dry wt (At large) for T. tonggol. and from $0.047 \mu \mathrm{g} / \mathrm{g}$ dry wt (At Medium) to $0.073 \mu \mathrm{g} / \mathrm{g}$ dry wt (At large) for $S$. jello and from $0.277 \mu \mathrm{g} / \mathrm{g}$ dry wt (at medium) to $0.312 \mu \mathrm{g} / \mathrm{g}$ dry wt (At large) for $E$. areolatus. The average concentration of Cadmium throughout all the three sizes in gill fish was 0.078 $\mu \mathrm{g} / \mathrm{g}$ dry wt (At Small) to $0.096 \mu \mathrm{g} / \mathrm{g}$ dry wt (At large) for $L$. mahsena and from $0.118 \mu \mathrm{g} / \mathrm{g}$ dry wt (at small) to $0.401 \mu \mathrm{g} / \mathrm{g}$ dry wt (at large) for T. tonggol. and from $0.068 \mu \mathrm{g} / \mathrm{g}$ dry wt (at medium) to $0.083 \mu \mathrm{g} / \mathrm{g}$ dry wt (At large) for $S$. jello and from $0.333 \mu \mathrm{g} / \mathrm{g}$ dry wt (At Medium) to $0.397 \mu \mathrm{g} / \mathrm{g}$ dry wt (At large) for $E$. areolatus. The high concentration of $\mathrm{Cd}$ $(0.365 \pm 0.032 \mu \mathrm{g} / \mathrm{g}$ dry wt.) was found in the Gill tissue of $E$. areolatus (Table 4), while in the lowest concentration of Cadmium level $(0.029 \pm 0.010 \mu \mathrm{g} / \mathrm{g}$ dry wt.) was detected in the muscle tissue of $S$. jello (Table 
4). The mean concentration of $\mathrm{Cd}$ varied from a minimum of $0.029 \pm 0.010, \quad 0.061 \pm 0.013$ and $0.077 \pm 0.008$ in $S$. jello, to a maximum value of
$0.069 \pm 0.021 ; 0.289 \pm 0.020$ and $0.365 \pm 0.032$ in $E$. areolatus Table 4.

Table 9: The covariance analysis between mean concentration of $\mathrm{Hg}(\mu \mathrm{g} / \mathrm{g})$ among in some types of fishes in Yemeni seas and different variables.

\begin{tabular}{lcccccc}
\hline Source & $\begin{array}{c}\text { Type III Sum of } \\
\text { Squares }\end{array}$ & df & $\begin{array}{c}\text { Mean } \\
\text { Square }\end{array}$ & F & P & $\begin{array}{c}\text { Partial Eta } \\
\text { Squared }\end{array}$ \\
\hline Corrected Model & $0.428^{\text {a }}$ & 11 & 0.039 & 79.945 & 0.000 & 0.738 \\
Intercept & 0.002 & 1 & 0.002 & 4.235 & 0.040 & 0.013 \\
Seasons & 0.001 & 2 & 0.000 & 0.970 & 0.380 & 0.006 \\
Tissue & 0.397 & 2 & 0.198 & 407.259 & 0.000 & 0.723 \\
Species & 0.024 & 3 & 0.008 & 16.126 & 0.000 & 0.134 \\
Site & 0.001 & 2 & 0.000 & 0.551 & 0.577 & 0.004 \\
Wight & 0.001 & 1 & 0.001 & 1.611 & 0.205 & 0.005 \\
Length & 0.001 & 1 & 0.001 & 1.367 & 0.243 & 0.004 \\
Error & 0.152 & 312 & 0.000 & & & \\
Total & 1.683 & 324 & & & & \\
Corrected Total & 0.580 & 323 & & & & \\
\hline \multicolumn{7}{c}{ a. R Squared $=0.738$ (Adjusted R Squared = 0.729) } \\
\end{tabular}

Table 10: The mean concentration of $\mathrm{Hg}(\mu \mathrm{g} / \mathrm{g})$ among the areas, type and the tissues of the fish.

\begin{tabular}{llccc}
\hline (I) Species & (J) Species & $\begin{array}{c}\text { Mean Difference } \\
(\mathbf{I}-\mathbf{J})\end{array}$ & Std. Error & $\mathbf{P}^{\mathbf{b}}$ \\
\hline $\begin{array}{l}\text { Lethrinusmahsena } \\
\text { Thunnustonggol }\end{array}$ & Thunnustonggol & $0.030^{*}$ & 0.007 & 0.000 \\
Sphyraenajello & E. areolatus & $-0.040^{*}$ & 0.007 & 0.000 \\
(I) Tissue & (J) Tissue & $-0.030^{*}$ & 0.007 & 0.000 \\
Muscles & Liver & & & \\
& Gill & $-0.043^{*}$ & 0.003 & 0.000 \\
Liver & Gill & $0.042^{*}$ & 0.003 & 0.000 \\
\hline
\end{tabular}

Based on estimated marginal means *. The mean difference is significant at the .05 level.b. Adjustment for multiple comparisons: Bonferroni.

Table 7 shows the covariance analysis between mean concentration of $\mathrm{Cd}$ among in some types of fishes in Yemeni seas and different variables. These different variables include; time, tissue, type and area of the fish. After included the weight and length factors to show the related impact in the change of concentration of $\mathrm{Cd}$ to the three periods of time, the covariance analysis was statistically significant in which the $(p<0.01)$. The mean concentration of $\mathrm{Cd}$ to the species of fish, among the tissues of the fish and among three different areas of fishing were also statistically significant with the $\mathrm{p}$ value are similar $(p<0.01)$, where the impact of these differences in concentration ratio of $\mathrm{Cd}$ were $(21 \%$, $27 \%$ and $6 \%$ ) respectively. Table 8 shows the mean concentration of $\mathrm{Cd}$ among the areas, type and the tissues of the fish. The concentration of $\mathrm{Cd}$ were concentrated at Between Al Mukalla and Aden , Al Hudaydah in which the mean concentration of $\mathrm{Cd}$ among fishes were $(0.048$ and 0.075$)$ Towards Aden, Al Hudaydah respectively, these results were statistically significant $(p<0.05)$. The differences in the mean concentration of $\mathrm{Cd}$ among the different types of the fishes were found between E. areolatus and three other types and the mean concentration was in $L$. mahsena (0.173), T. tonggol (0.246) and S. jello (0.182), The direction of the type of fish E. areolatus, these difference was statistically significant $(p<0.01)$. According the concentration of $\mathrm{Cd}$ among the tissues of the fish was found among the muscles and liver (0.086), muscles and gill (0.149) The direction of the average lead concentration in the liver and Gill respectively, and liver and gill (0.064) The direction of the average lead concentration in the Gill and these results were statistically significant $(p<0.01)$. The focus of statistical significance in the ratio of the concentration of cadmium between time stages in 2011 differences than between 2012 and 2013 on the one hand and the differences towards the point in time in 2012 a difference in average (0.052) and stage time in 2013 a difference of $(0.052)$ and at the level of statistical significance $(p<0.01)$.

\section{Mercury}

The average concentration of Mercury throughout all the three Sizes in Muscles Fish was $0.062 \mu \mathrm{g} / \mathrm{g}$ dry wt (At Small ) to $0.063 \mu \mathrm{g} / \mathrm{g}$ dry wt (At large) for $L$. mahsenaand from $0.023 \mu \mathrm{g} / \mathrm{g}$ dry wt (At Small ) to $0.036 \mu \mathrm{g} / \mathrm{g}$ dry wt (At large) for T. tonggol. and from $0.056 \mu \mathrm{g} / \mathrm{g}$ dry wt (At Small) to $0.078 \mu \mathrm{g} / \mathrm{g}$ dry wt (At large) for $S$. jello and from $0.058 \mu \mathrm{g} / \mathrm{g}$ dry wt (At Small) to $0.083 \mu \mathrm{g} / \mathrm{g}$ dry wt (At large) for E. areolatus. The average concentration of Mercury throughout all the three Sizes in Liver Fish was $0.093 \mu \mathrm{g} / \mathrm{g}$ dry wt (At Small) to $0.063 \mu \mathrm{g} / \mathrm{g}$ dry wt (At large) for $L$. mahsenaand from $0.098 \mu \mathrm{g} / \mathrm{g}$ dry wt (At Small ) to $0.149 \mu \mathrm{g} / \mathrm{g}$ dry wt (At large) for T. tonggol. and from $0.043 \mu \mathrm{g} / \mathrm{g}$ dry wt (At Small) to $0.074 \mu \mathrm{g} / \mathrm{g}$ dry wt (At 
large) for $S$. jello and from $0.106 \mu \mathrm{g} / \mathrm{g}$ dry wt (At Small) to $0.141 \mu \mathrm{g} / \mathrm{g}$ dry wt (At large) for E. areolatus. The average concentration of Mercury throughout all the three Sizes in Gill Fish was $0.011 \mu \mathrm{g} / \mathrm{g}$ dry wt (At Small) to $0.016 \mu \mathrm{g} / \mathrm{g}$ dry wt (At large) for $L$. mahsenaand from $0.015 \mu \mathrm{g} / \mathrm{g}$ dry wt (At Small ) to $0.025 \mu \mathrm{g} / \mathrm{g}$ dry wt (At large) for T. tonggol. and from $0.016 \mu \mathrm{g} / \mathrm{g}$ dry wt (At Small) to $0.022 \mu \mathrm{g} / \mathrm{g}$ dry wt (At large) for $S$. jello and from $0.009 \mu \mathrm{g} / \mathrm{g}$ dry wt (At Small) to $0.011 \mu \mathrm{g} / \mathrm{g}$ dry wt (At large) for E. areolatus.

Table 11: The covariance analysis between mean concentration of $\mathrm{As}(\mu \mathrm{g} / \mathrm{g})$ among in some types of fishes in Yemeni seas and different variables.

\begin{tabular}{lcccccc}
\hline Source & $\begin{array}{c}\text { Type III Sum of } \\
\text { Squares }\end{array}$ & df & $\begin{array}{c}\text { Mean } \\
\text { Square }\end{array}$ & F & P & $\begin{array}{c}\text { Partial Eta } \\
\text { Squared }\end{array}$ \\
\hline Corrected Model & $0.446^{\mathrm{a}}$ & 11 & 0.041 & 72.024 & 0.000 & 0.717 \\
Intercept & 0.005 & 1 & 0.005 & 9.118 & 0.003 & 0.028 \\
Seasons & 0.000 & 2 & 0.000 & 0.023 & 0.977 & 0.000 \\
Tissue & 0.370 & 2 & 0.185 & 328.712 & 0.000 & 0.678 \\
Species & 0.030 & 3 & 0.010 & 17.989 & 0.000 & 0.147 \\
Site & 0.009 & 2 & 0.004 & 7.855 & 0.000 & 0.048 \\
Wight (Kg) & 0.005 & 1 & 0.005 & 9.093 & 0.003 & 0.028 \\
Length (M) & 0.000 & 1 & 0.000 & 0.452 & 0.502 & 0.001 \\
Error & 0.176 & 312 & 0.001 & & & \\
Total & 2.666 & 324 & & & & \\
Corrected Total & 0.622 & 323 & & & & \\
\hline
\end{tabular}

a. $\mathrm{R}$ Squared $=0.717$ (Adjusted R Squared $=0.707$ )

Table 12: The mean concentration of As $(\mu \mathrm{g} / \mathrm{g})$ among the areas, type and the tissues of the fish.

\begin{tabular}{|c|c|c|c|c|}
\hline (I) Species & (J) Species & $\begin{array}{c}\text { Mean Difference } \\
\text { (I-J) }\end{array}$ & Std. Error & $\mathbf{P}^{\mathbf{b}}$ \\
\hline \multirow[t]{2}{*}{ Lethrinusmahsena } & Thunnustonggol & $0.049^{*}$ & 0.007 & 0.000 \\
\hline & Sphyraenajello & $0.033^{*}$ & 0.007 & 0.010 \\
\hline Thunnustonggol & E. areolatus & $-0.049 *$ & 0.006 & 0.000 \\
\hline Sphyraenajello & E. areolatus & $-0.033 *$ & 0.006 & 0.010 \\
\hline (I) Tissue & (J) Tissue & & & \\
\hline \multirow[t]{2}{*}{ Muscles } & Liver & $-0.027 *$ & 0.003 & 0.000 \\
\hline & Gill & $0.055^{*}$ & 0.003 & 0.000 \\
\hline Liver & Gill & $0.081^{*}$ & 0.003 & 0.000 \\
\hline (I) Site & (J) Site & & & \\
\hline Aden & Al Mukalla & $-0.013 *$ & 0.003 & 0.000 \\
\hline
\end{tabular}

Based on estimated marginal means *. The mean difference is significant at the .05 level. b. Adjustment for multiple comparisons: Bonferroni.

The high concentration of $\mathrm{Hg}(0.127 \pm 0.026 \mu \mathrm{g} / \mathrm{g}$ dry wt.) was found in the livers tissue of T. tonggol (Table 4 ), while in the lowest concentration of Mercury level $(0.010 \pm 0.001 \mathrm{~g} / \mathrm{g}$ dry wt.) was detected in the gills tissue of $E$. areolatus (Table 4). The mean concentration of $\mathrm{Hg}$ in the muscles, livers and gills of the four studied fish species varied from a minimum of $0.030 \pm 0.006,0.060 \pm 0.016$ and $0.010 \pm 0.001$ in $T$. tonggol, $S$. jello and E. areolatus, to a maximum value of $0.071 \pm 0.012 ; 0.127 \pm 0.026$ and $0.020 \pm 0.005$ in $E$. areolatus, $T$. tonggol (Table 4). Table 9 shows the covariance analysis between mean concentration of $\mathrm{Hg}$ among in some types of fishes in Yemeni seas and different variables. These different variables include; tissue and type of the fish. After included the weight and length factors to show the related impact in the change of concentration of $\mathrm{Hg}$ to the three periods of time and area, the covariance analysis was not statistically significant in which the $(p>0.05)$.

The mean concentration of $\mathrm{Hg}$ to the species of fish, among the tissues of the fish were also statistically significant with the $\mathrm{p}$ value are similar $(p<0.01)$, where the impact of these differences in concentration ratio of $\mathrm{Hg}$ were $(72 \%, 13 \%)$ respectively, and not statistically significant in the among three different areas of fishing. Table 10 shows the differences in the mean concentration of $\mathrm{Hg}$ among the different types of the fishes were found between L. mahsena and T. tonggol, $T$. tonggol and E. areolatus, $S$. jello and $E$. areolatus $(0.030),(0.040)$ and $(0.030)$ respectively, The 
direction of the type of fish L. mahsena and $E$. areolatus, these difference was statistically significant $(p<0.01)$. According the concentration of $\mathrm{Hg}$ among the tissues of the fish was found among the muscles and liver (0.043), muscles and gill (0.042) The direction of the average lead concentration in the liver and muscles respectively, and liver and gill (0.086) The direction of the average lead concentration in the liver and these results were statistically significant ( $\mathrm{p}$ $<0.01$ ).

\section{Arsenic}

The average concentration of Arsenic throughout all the three Sizes in Muscles Fish was $0.100 \mu \mathrm{g} / \mathrm{g}$ dry wt (At Small) to $0.114 \mu \mathrm{g} / \mathrm{g}$ dry wt (At large) for $L$. mahsena and from $0.045 \mu \mathrm{g} / \mathrm{g}$ dry wt (At Small ) to $0.100 \mu \mathrm{g} / \mathrm{g}$ dry wt (At large) for T. tonggol. and from $0.077 \mu \mathrm{g} / \mathrm{g}$ dry wt (At Small) to $0.103 \mu \mathrm{g} / \mathrm{g}$ dry wt (At large) for $S$. jello and from $0.078 \mu \mathrm{g} / \mathrm{g}$ dry wt (At Small) to $0.099 \mu \mathrm{g} / \mathrm{g}$ dry wt (At large) for E. areolatus. The average concentration of Arsenic throughout all the three Sizes in Liver Fish was $0.114 \mu \mathrm{g} / \mathrm{g}$ dry wt (At Small) to $0.128 \mu \mathrm{g} / \mathrm{g}$ dry wt (At large) for L. mahsena and from $0.121 \mu \mathrm{g} / \mathrm{g}$ dry wt (At Small ) to $0.184 \mu \mathrm{g} / \mathrm{g}$ dry wt (At large) for T. tonggol. and from $0.053 \mu \mathrm{g} / \mathrm{g}$ dry wt (At Small) to $0.087 \mu \mathrm{g} / \mathrm{g}$ dry wt (At large) for $S$. jelloand from $0.114 \mu \mathrm{g} / \mathrm{g}$ dry wt (At Small) to 0.134 $\mu \mathrm{g} / \mathrm{g}$ dry wt (At large) for E. areolatus. The average concentration of Arsenic throughout all the three Sizes in Gill Fish was $0.020 \mu \mathrm{g} / \mathrm{g}$ dry wt (At Small) to $0.032 \mu \mathrm{g} / \mathrm{g}$ dry wt (At large) for L. mahsena and from $0.027 \mu \mathrm{g} / \mathrm{g}$ dry wt (At Small ) to $0.060 \mu \mathrm{g} / \mathrm{g}$ dry wt (At large) for T. tonggol. and from $0.020 \mu \mathrm{g} / \mathrm{g}$ dry wt (At Small) to $0.029 \mu \mathrm{g} / \mathrm{g}$ dry wt (At large) for $S$. jelloand from $0.042 \mu \mathrm{g} / \mathrm{g}$ dry wt (At Small) to $0.048 \mu \mathrm{g} / \mathrm{g}$ dry wt (At large) for $E$. areolatus. The high concentration of As $(0.147 \pm 0.032 \mu \mathrm{g} / \mathrm{g}$ dry wt. $)$ was found in the livers tissue of $T$. tonggol (Table 4), while in the lowest concentration of Arsenic level $(0.025 \pm 0.005 \mu \mathrm{g} / \mathrm{g}$ (dry wt.) was detected in the gills tissue of $S$. jello (Table 4). The mean concentration of As in the muscles, livers and gills of the four studied fish species varied from a minimum of $0.071 \pm 0.028, \quad 0.070 \pm 0.017$ and $0.025 \pm 0.005 \mu \mathrm{g} / \mathrm{g}$ (dry wt.) in T. tonggol, S. jello and $S$. jello, to a maximum value of $0.132 \pm 0.048$; $0.147 \pm 0.032$ and $0.045 \pm 0.003 \mu \mathrm{g} / \mathrm{g}$ (dry wt.) in $E$. areolatus, T. tonggol and E. areolatus Table 4. Table 11 shows the covariance analysis between mean concentration of As among in some types of fishes in Yemeni seas and different variables. These different variables include; tissue, type and area of the fish. After included the weight and length factors to show the related impact in the change of concentration of As to the three periods of time, the covariance analysis was not statistically significant in which the $(p>0.05)$. The mean concentration of As to the species of fish, among the tissues of the fish and among three different areas of fishing were also statistically significant with the $\mathrm{p}$ value are similar $(p<0.01)$, where the impact of these differences in concentration ratio of As were $(68 \%, 15 \%$ and $5 \%)$ respectively. Table 12 shows the mean concentration of As among the areas, type and the tissues of the fish. The concentration of As were concentrated at Between Aden and Al Mukalla in which the mean concentration of As among fishes were (0.013) Towards Al Mukalla, these results were statistically significant $(p<0.01)$. The differences in the mean concentration of As among the different types of the fishes were found between L. mahsena and two other types and the mean concentration was in $T$. tonggol (0.049) and S. jello(0.033). The direction of the type of fish $L$. mahsena, these difference was statistically significant $(p<0.05)$. and the differences in the mean concentration of $\mathrm{Hg}$ among the different types of the fishes were found between T. tonggol and E. areolatus, S. jello and E. areolatus (0.049), (0.033) respectively, The direction of the type of fish $E$. areolatus, these difference was statistically significant $(p<0.05)$. According the concentration of As among the tissues of the fish was found among the muscles and liver (0.027), muscles and gill (0.055) The direction of the average lead concentration in the liver and muscles respectively, and liver and gill (0.081) The direction of the average lead concentration in the liver and these results were statistically significant $(\mathrm{p}<0.01)$.

\section{Statistically Evaluation}

The details of analysis of each statics ANOVA

\section{Correlation analyses between metals in Muscles}

The relationship between metals level in Muscles tissue are represented by correlation coefficient ( $r$ ) in Table 13. Notes from the Table 13 above for the province of Aden and the presence of significant positive correlations at the level of $(p<0.01)$ between the $\mathrm{Pb}$ in fish muscle tissue with $\mathrm{Cd}$ in the same Muscle tissue, also has been associated with $\mathrm{Cd}$ morally significant positive correlations at the level of $(p<0.01)$ with As in the same Muscle tissue, and has been associated with $\mathrm{Hg}$ significant positive correlations morally at a level $(p<0.01)$ with As in the same Muscle tissue. In AlHudaydah site, showed a significant positive correlations at a level $(p<0.01)$ between the $\mathrm{Pb}$ in fish muscle tissue with $\mathrm{Cd}$ and at a level $(p<0.05)$ with As in the same Muscle tissue, also it has been associated with $\mathrm{Cd}$ closely morally significant positive correlations at the level of $(p<0.05)$ with $\mathrm{Hg}$ and As $\mathrm{Hg}$ in the same fabric, and has been associated with $\mathrm{Hg}$ significant positive correlations morally at a level $(p<0.01)$ with As in the same Muscle tissue.

\section{Correlation analyses between metals in liver}

The relationship between metals level in Liver tissue are represented by correlation coefficient (r) in Table 14. Notes from the Table 14 above for the Aden site and the presence of significant positive correlations at the level of $(p<0.01)$ between the $\mathrm{Pb}$ in the tissue of fish liver with As in the same Liver tissue, also has been associated with $\mathrm{Cd}$ significant positive correlations morally at a level $(p<0.01)$ with $\mathrm{Hg}$ and As in the same Liver tissue, and has been associated with $\mathrm{Hg}$ significant positive correlations morally at a level $(p<0.01)$ with As in the same Liver tissue. In AlHudaydah site, show a significant positive correlations at a level $(p<0.05)$ between the $\mathrm{Cd}$ into the tissue of fish liver with As in the same Liver tissue, also has been associated with $\mathrm{Hg}$ significant positive correlations morally at a level $(p<0.01)$ into the fabric of fish liver As with metal arsenic in the same Liver tissue. In AL-Mukallala site, show a significant 
positive correlations at the level of $(p<0.05)$ between the $\mathrm{Pb}$ in the tissue of fish liver with $\mathrm{Hg}$ and $\mathrm{As}$ in the same Liver tissue, and has been associated with $\mathrm{Cd}$ into the tissue of fish liver significant positive correlations morally at a level $(p<0.01)$ with $\mathrm{Hg}$ and
As in the same Liver tissue, also has been associated with $\mathrm{Hg}$ in fish liver tissue was significant positive correlations at the level of $(p<0.01)$ with As in the same Liver tissue.

Table 13: Correlation analyses between metals in muscles tissue

\begin{tabular}{lccccc}
\hline Site & & Pb & Cd & Hg & As \\
\hline Aden & $\mathrm{Pb}$ & 1 & - & - & - \\
& $\mathrm{Cd}$ & $0.673^{* *}$ & 1 & - & - \\
& $\mathrm{Hg}$ & 0.133 & 0.325 & 1 & - \\
& $\mathrm{As}$ & 0.208 & $0.454^{* *}$ & $0.771^{* *}$ & 1 \\
\hline AL- Hudaydah & $\mathrm{Pb}$ & 1 & - & - & - \\
& $\mathrm{Cd}$ & $0.624^{* *}$ & 1 & - & - \\
& $\mathrm{Hg}$ & -0.046 & $0.390^{*}$ & 1 & - \\
& $\mathrm{As}$ & $0.399^{*}$ & $0.339^{*}$ & $0.472^{* *}$ & 1 \\
\hline AL- Mukalla & $\mathrm{Pb}$ & 1 & - & - & - \\
& $\mathrm{Cd}$ & $0.491^{* *}$ & 1 & - & - \\
& $\mathrm{Hg}$ & -0.072 & $0.494^{* *}$ & 1 & - \\
& $\mathrm{As}$ & 0.226 & 0.132 & $0.383^{*}$ & 1 \\
\hline
\end{tabular}

Significant correlation $(P<0.05) ;{ }^{* *}$ Significant correlation $(P<0.01)$

\section{Correlation analyses between metals in Gill}

The relationship between metals level in Gill tissue are represented by correlation coefficient $(r)$ in Table 15 . Notes from the Table 15 for the Aden site and the presence of significant negative correlations at the level of $(p<0.01)$ between the $\mathrm{Pb}$ in the tissue of the gills of fish with $\mathrm{Hg}$ in the same gill, while linked to $\mathrm{Hg}$ in the tissue of the gills of fish significant positive correlations morally at a level $(p<0.01)$ with As in the same gill. In Al-Hudaydah site, showed a significant negative correlations at the level of $(p<0.05)$ between the $\mathrm{Pb}$ in the tissue of the gills of fish with $\mathrm{Cd}$ in the same gill, while correlation to $\mathrm{Hg}$ in the tissue of the gills of fish significant positive correlations morally at a level $(p<0.01)$ with As in the same gill. In ALMukallala site, showed a significant negative correlations at the level of $(p<0.05)$ between the $\mathrm{Pb}$ in the tissue of the gills of fish with $\mathrm{Hg}$ and as in the same gill, and has been associated with $\mathrm{Hg}$ is significant negative correlations at the level of $(p<0.01)$ with As in the same gill, while the $\mathrm{Cd}$ was associated in the gills of fish tissue significant positive correlations morally closely at the level of $(p<0.05)$ with $\mathrm{Hg}$ in the same gill.

\section{DISCUSSION}

\section{Heavy Metals in different Organs}

During the present study, $\mathrm{Pb}$ levels have been seen to be maximum in gill from $L$. mahsena and $S$. jello, and in liver from $T$. tonggol and $E$. areolatus, minimum in muscle in all the fish species. Cd levels, too, are found to be maximum in gill, minimum in muscle and intermediate in liver in all the fish species. $\mathrm{Hg}$ and $\mathrm{As}$ levels, are found to be maximum in liver in all the fish species, except $S$. jello It was higher in muscle, minimum in gill in all the fish species and intermediate in muscle in all the fish species except $S$. jello. In all the investigated fish species, L. mahsena, T. tonggol, $S$. jelloand E. areolatus, gill accumulates the highest levels of $\mathrm{Pb}$ and $\mathrm{Cd}$. Liver accumulates the highest levels of $\mathrm{Hg}$ and As. The highest accumulation of metals in gill as compared to other organs has been recorded a similar trend has been observed in $E$. fasciatus in a previous study ${ }^{19}$ and in E. areolatus in anothter previous study ${ }^{20}$. The highest accumulation of metals in liver as compared to other organs has been widely recorded in earlier studies conducted in previous studies ${ }^{21-30}$. Liver is the major detoxification organ and many poisonous materials absorbed from the environment are detoxified in the liver. Studies carried out with different fish species have shown that heavy metals accumulate mainly in metabolically active liver that stores metals to detoxicate by producing metallothioneins ${ }^{31}$. Metallothioneins (MTs) are cysteine rich low molecular weight proteins having capacity to bind to physiological as well as xenobiotic heavy metals through a thiol group of cysteine. The higher levels of trace elements in liver relative to other tissues are, therefore, attributed to the affinity of MT proteins with these heavy elements ${ }^{32}$. During the present study, muscle of all the fish species has been found to accumulate lesser metals as compared to liver and gill. Muscle tissue is not considered to be an active site for metal accumulation ${ }^{33,34}$. Studies comparing the metal accumulation in muscle and liver of fish show lower metal concentration in the former. This trend has been recorded in marine fishes, in L. mahsena, in a previous study ${ }^{35,36,37}$, in $T$. albacores, a study ${ }^{38}$, in $S$. putnamae, in a study and in Soleasolea, and Sparusaurata, by another researdhers ${ }^{27}$. Cd and $\mathrm{Pb}$, have no biological role and hence they are harmful to living organisms even at considerably low concentrations. In this study, the overall mean concentrations of metals were found to accumulate in the order of $\mathrm{Pb}>\mathrm{Hg}>\mathrm{As}>\mathrm{Cd}$, Except in Fish species $S$. jello mean concentrations of metals were found to accumulate in the order of $\mathrm{Hg}>\mathrm{As}>\mathrm{Pb}>\mathrm{Cd}$. Although it is not always the rule, these results were in 
conformity with the observations of Al sulami, 2002 $(\mathrm{Pb}>\mathrm{Hg}>\mathrm{Cd}>\mathrm{As})$ and Burger et al., $(\mathrm{Hg}>\mathrm{As}>\mathrm{Pb}>\mathrm{Cd})$. Analysis of heavy metals in sediments offers more convenient and more accurate means of detecting and assessing the degree of water pollution ${ }^{40}$. Although it is well known that fish muscle is not an active tissue in accumulating heavy metals ${ }^{41}$, the present study concerned with the heavy metal concentrations in the fish muscles because it is the most consumed portion by the Yemen people. Furthermore it was documented that some fish in polluted regions may accumulate substantial amounts of metals in their tissues which sometimes exceeded the maximum acceptable levels.

Table 14: Correlation analyses between metals in liver tissue.

\begin{tabular}{lccccc}
\hline Site & & $\mathbf{P b}$ & $\mathbf{C d}$ & $\mathbf{H g}$ & As \\
\hline Aden & $\mathrm{Pb}$ & 1 & - & - & - \\
& $\mathrm{Cd}$ & 0.266 & 1 & - & - \\
& $\mathrm{Hg}$ & 0.194 & $0.474^{* *}$ & 1 & - \\
& $\mathrm{As}$ & $0.510^{* *}$ & $0.481^{* *}$ & $0.805^{* *}$ & 1 \\
\hline AL- Hudaydah & $\mathrm{Pb}$ & 1 & - & - & - \\
& $\mathrm{Cd}$ & -0.202 & 1 & - & - \\
& $\mathrm{Hg}$ & -0.176 & 0.325 & 1 & - \\
& $\mathrm{As}$ & 0.093 & $0.331^{*}$ & $0.887^{* *}$ & 1 \\
\hline AL- Mukalla & $\mathrm{Pb}$ & 1 & - & - & - \\
& $\mathrm{Cd}$ & 0.123 & 1 & - & - \\
& $\mathrm{Hg}$ & $0.375^{*}$ & $0.584^{* *}$ & 1 & - \\
& $\mathrm{As}$ & $0.367^{*}$ & $0.493^{* *}$ & $0.560^{* *}$ & 1 \\
\hline
\end{tabular}

Table 15: Correlation analyses between metals in gill tissue

\begin{tabular}{lccccc}
\hline Site & & Pb & Cd & Hg & As \\
\hline Aden & $\mathrm{Pb}$ & 1 & - & - & - \\
& $\mathrm{Cd}$ & -0.294 & 1 & - & - \\
& $\mathrm{Hg}$ & $-0.554^{* *}$ & 0.183 & 1 & - \\
& $\mathrm{As}$ & 0.006 & 0.083 & $0.652^{* *}$ & 1 \\
\hline AL- Hudaydah & $\mathrm{Pb}$ & 1 & - & - & - \\
& $\mathrm{Cd}$ & $-0.357^{*}$ & 1 & - & - \\
& $\mathrm{Hg}$ & -0.065 & -0.298 & 1 & - \\
& $\mathrm{As}$ & 0.173 & -0.200 & $0.822^{* *}$ & 1 \\
\hline AL- Mukalla & $\mathrm{Pb}$ & 1 & - & - & - \\
& $\mathrm{Cd}$ & -0.134 & 1 & - & - \\
& $\mathrm{Hg}$ & $-0.393^{*}$ & $0.363^{*}$ & 1 & - \\
& $\mathrm{As}$ & $-0.382^{*}$ & 0.090 & - & 1 \\
& & & & $0.499^{* *}$ & \\
\hline
\end{tabular}

${ }^{*}$ Significant correlation $(P<0.05) ;{ }^{* *}$ Significant correlation $(P<0.01)$

Lead accumulation in different organs showed the order L. mahsena $>$ E. areolatus $>$ T. tonggol $>S$. jello. Overall ranking revealed from the results that among the four fish species the L. mahsena accumulated the highest concentration of all the heavy metals, which indicates that this species have more potential to accumulate these metals in each liver and gills. It may be due to the feeding habits of the fish, lipid content in the tissue and excretion percentage of these toxic metals from their body. Cadmium, Mercury and Arsenic accumulation in different organs showed the order E. areolatus $>T$. tonggol $>L$. mahsena $>S$. jello. The arrangement order of $\mathrm{Pb}$ and $\mathrm{Cd}$ content in tissues of the polluted fish was gill >liver $>$ muscle, whereas in case of $\mathrm{Hg}$ and $\mathrm{As}$ the order was liver $>$ gill $>$ muscle (Table 4).

Heavy metal concentrations vs. International dietary standards and guidelines.

Lead
The FAO/WHO ${ }^{42}$ and Yemen Standardization ${ }^{43}$ guidelines for a prescribed maximum permissible limit of Lead in Fish are $1.50 \mu \mathrm{g} / \mathrm{g}$ (dry wt.) and $1.00 \mu \mathrm{g} / \mathrm{g}$ (dry wt.). The main highest concentration of $\mathrm{Pb}$ in the muscles, livers and gills of the four studied fish species was $0.137 \pm 0.014 \mu \mathrm{g} / \mathrm{g}$ (dry wt.) in large E. areolatus and $0.428 \pm 0.031 ; 0.845 \pm 0.009 \mu \mathrm{g} / \mathrm{g}$ (dry wt.) in $L$. mahsena. At site AL- Hudaydah. The values obtained for $\mathrm{Pb}$ in the muscles, livers and gills were below the $\mathrm{Pb}$ prescribed standard safe limits of $1.00-1.50 \mu \mathrm{g} / \mathrm{g}$ dry wt. ) for food fish $\left(\mathrm{FAO} / \mathrm{WHO}^{42}\right.$ and standard specification for Yemen ${ }^{43}$. Based on this information, Yemen coast in the present study is low polluted when it is compared with other locations.

\section{Cadmium}

The FAO/WHO ${ }^{42}$ and Yemen Standardization $^{43}$ guidelines for a prescribed maximum permissible limit of Cadmium in Fish are $1.00 \mu \mathrm{g} / \mathrm{g}$ (dry wt.) and 0.2 $\mu \mathrm{g} / \mathrm{g}$ (dry wt.). In summer, the main highest concentration of Cadmium in the muscles and livers of 
the four studied fish species were $0.069 \pm 0.021$ and $0.289 \pm 0.020 \mu \mathrm{g} / \mathrm{g}$ (dry wt.) in large E. areolatus in Year 2012 at Site AL- Hudaydah whereas in gills was having $0.365 \pm 0.032 \mu \mathrm{g} / \mathrm{g}$ (dry wt.) in E. areolatus in Year 2012 at Site Aden. The values obtained for $\mathrm{Cd}$ in the muscles, livers and gills were below the $\mathrm{Cd}$ prescribed standard safe limits of $1.0 \mu \mathrm{g} / \mathrm{g}$ (dry wt.) for food fish $\mathrm{FAO} / \mathrm{WHO}^{42}$. But, the Yemen Standardization $^{43}$ guidelines for maximum permissible limit of Cadmium in Fish are given as $0.2 \mu \mathrm{g} / \mathrm{g}$ (dry wt.). As the range of Cadmium detected was higher than the permissible limit in livers and gills $E$. areolatus and gills T. tonggol fish.

\section{Mercury}

The FAO/ $\mathrm{WHO}^{42}$ and Yemen standardization ${ }^{43}$ guidelines for prescribed maximum permissible limit of Mercury in Fish are $0.50 \mu \mathrm{g} / \mathrm{g}$ (dry wt.). The main highest concentration of $\mathrm{Hg}$ in the muscles, livers and gills of the four studied fish species was $0.071 \pm 0.012 \mu \mathrm{g} / \mathrm{g}$ (dry wt.) in E. areolatus (at large); $0.127 \pm 0.026$ and $0.020 \pm 0.005 \mu \mathrm{g} / \mathrm{g}$ (dry wt.) in large $T$. tonggolat Site AL-Mukalla. The FAO/WHO ${ }^{42}$ and Yemen Standardization ${ }^{43}$ guidelines for prescribed maximum permissible limit of Mercury in Muscles Fish are $0.50 \mu \mathrm{g} / \mathrm{g}$ (dry wt.). As the detected Mercury remained below the $\mathrm{FAO} / \mathrm{WHO}^{42}$ and Yemen Standardization ${ }^{43}$ permissible limits.

\section{Arsenic}

The FAO/ $\mathrm{WHO}^{42}$ and Yemen Standardization ${ }^{43}$ guidelines for a prescribed maximum permissible limit of Arsenic in Fish are $0.10-5.00 \mu \mathrm{g} / \mathrm{g}$ (dry wt.) and 1.0 $\mu \mathrm{g} / \mathrm{g}$ (dry wt.). The main highest concentration of As in the muscles, livers and gills of the four studied fish species was $0.106 \pm 0.007 \mu \mathrm{g} / \mathrm{g}$ (dry wt.) in L. mahsena (at large); $0.147 \pm 0.032 \mu \mathrm{g} / \mathrm{g}$ (dry wt.) in T. tonggol (at large) and $0.045 \pm 0.003 \mu \mathrm{g} / \mathrm{g}$ (dry wt.) in Epinephelus areolatus at Site AL-Mukalla. As the detected Arsenic remained below the $\mathrm{FAO} / \mathrm{WHO}^{42}$ and Yemen Standardization $^{43}$ permissible limits.

\section{CONCLUSION}

The Fish samples were collected from the Three different Cities of Yemeni coasts. Aden, Al-Hodeidah and AL-Mukalla were chosen for the sample collection. Lethrinusmahsena, Thunnustonggol, Sphyraenajello and Epinephelus areolatus fish samples were considered for the study as they are more common eatable fish among the population. The study was carried out in the all three seasons of winter 2011, summer 2012 and winter 2013 in order to check seasonal variation of heavy metal pollution. Total fish (108 samples of each muscles, liver and gills) were analyzed. The four heavy metals lead, Cadmium, Mercury and arsenic which are considered highly toxic were detected in the samples in the year 2010, 2012 and 2013. Four species of fish Lethrinusmahsena, Thunnustonggol, Sphyraenajello and Epinephelus areolatus was examined and Lead, Cadmium, Mercury and Arsenic concentra. The highest mean concentration of $\mathrm{Pb}$ in the muscles, livers and gills of the four studied fish species was $0.137 \pm 0.014 \mu \mathrm{g} / \mathrm{g}$ dry wt in large Epinephelusareolatus and $0.428 \pm$ $0.031 ; 0.845 \pm 0.009 \mu \mathrm{g} / \mathrm{g}$ dry wt in Lethrinusmahsena at Site AL- Hudaydah. The values obtained for $\mathrm{Pb}$ in the muscles, livers and gills were below the $\mathrm{Pb}$ prescribed standard safe limits of $1.00-1.50 \mu \mathrm{g} / \mathrm{g}$ dry wt. (for food fish (FAO/WHO ${ }^{42}$ and Standard Specification for $\mathrm{Yemen}^{43}$ ). The values obtained for $\mathrm{Cd}$ in the muscles, livers and gills were below the $\mathrm{Cd}$ prescribed standard safe limits of $1.0 \mu \mathrm{g} / \mathrm{g}$ (dry wt) for food fish. But, the Standard Specification for Yemen ${ }^{43}$ guidelines for maximum permissible limit of Cadmium in Fish are given as $0.2 \mu \mathrm{g} / \mathrm{g}$ dry wt. The highest mean concentration of $\mathrm{Hg}$ in the muscles, livers and gills of the four studied fish species was $0.071 \pm 0.012 \mu \mathrm{g} / \mathrm{g}$ (dry wt) in Epinephelusareolatus (at large) ; $0.127 \pm 0.026$ and $0.020 \pm 0.005 \mu \mathrm{g} / \mathrm{g}$ (dry wt) in large Thunnustonggol at Site AL-Mukalla.

The WHO and Standard Specification for Yemen ${ }^{43}$ guidelines for prescribed maximum permissible limit of Mercury in Muscles Fish are $0.50 \mu \mathrm{g} / \mathrm{g}$ dry wt. As the detected Mercury remained below the WHO and Standard Specification for Yemen ${ }^{43}$ permissible limits. The highest mean concentration of As in the muscles, livers and gills of the four studied fish species was $0.106 \pm 0.007$ in Lethrinusmahsena (at large) ; $0.147 \pm 0.032$ in Thunnustonggol (at large) and $0.045 \pm 0.003 \mu \mathrm{g} / \mathrm{g}$ (dry wt.) in Epinephelusareolatus at Site AL-Mukalla. As the detected Arsenic remained below the $\mathrm{FAO} / \mathrm{WHO}^{42}$ and Yemen Standardization (2006) permissible limits. From the heavy metal concentrations mentioned above we can see that somewhere the concentration is crossing the limits as permissible by the World Health Organization

\section{AUTHOR'S CONTRIBUTION}

The manuscript was carried out, written, and approved in collaboration with all authors.

\section{ACKNOWLEDGEMENTS}

The authors extend their thanks and appreciation to the Sana'a University, Sana'a-Yemen to provide necessary facilities for this work.

\section{CONFLICT OF INTEREST}

No conflict of interest associated with this work.

\section{REFERENCES}

1. Olaifa FE, Olaifa AK, Adelaja AA, Owolabi AG. Heavy metal concentration of Clarias gariepinus from a lake and fish from in Ibadan, Nigeria. Afr J Biomed Res 2004; 7, 145-148 https://doi.org/10.1186/s40201-015-0222-y

2. Burger J, Gaines KF, Boring S et al., Metals levels in fish from the Savannah River: Potential hazards to fish and other receptors. Environ Res 2002; 89, 95-97 https://doi.org/10.1006/enrs.2002.4330

3. Clearwater SJ, Baskin SJ, Wood CM, MacDonald. Gastrointestinal uptake and distribution of copper in rainbow trout. J Exp Biol 2000; 203, 2455-2466

4. Van den Broek JI, Gledhill KS, Morgan DG. Heavy metal concentration in the Mosquito fish Gambusiaholbrooki in the manly Lagoon Gatchment. In: UTS, fresh water ecological report 2002 department of environmental Science, University of Technology, Sydney 2002;1-25

5. Schulz UH, Martins-Junior, H. Astyanafaseiatus as bio indicator of water pollution of Rio Dos Sinos, Rs, Brazil. Braz J Biol 2001; 61(4): 615-622. 
6. Ebrahimi M, Taherianfard M. The effects of heavy metals exposure on reproductive systems of cyprinid fish from Kor River. Iranian J Fisheries Sci. 2011; 10(1): 13-24.

7. Eneji I, Sha'Ato, R. Annune, P. Bioaccumulation of Heavy Metals in Fish (Tilapia Zilli and Clarias Gariepinus) Organs from River Benue, North-Central Nigeria. Pakistan J Analytical Environ Chem 2011; 12(1):2.

8. Strydom C, Robinson C, Pretorius E. The effect of selected metals on the central metabolic pathways in biology: a review. Water SA 2006; 32(4): 543-554. https://doi.org/10.1038/nrm2972

9. Alhashemi AH, Sekhavatjou MS, Hassanzadeh Kiabi B, Karbassi AR. Bioaccumulation of trace elements in water, sediment, and six fish species from a freshwater wetland, Iran. Microchemical J 2012; 104: 1-6. https://doi.org/10.1016/j.microc.2012.03.002

10. Zhao S, Feng C, Quan W, Chen X, Niu J, Shen Z. Role of living environments in the accumulation characteristics of heavy metals in fishes and crabs in the Yangtze River Estuary, China. Marine Pollution Bull 2012; 64(6):1163-71. https://doi.org/10.1016/j.marpolbul.2012.03.023

11. Davies OA, Allison ME, Uyi HS. Bioaccumulation of heavy metals in water, sediment and periwinkle (Tympanotonusfuscatusvar radula) from the Elechi Creek, Niger Delta. African J Biotech. 2006; 5(10) 968-973.

12. Statistical Year-Book. Republic of Yemen, Ministry of Planning and Development, (Sana'a: Central Statistical Organisation) 2013.

13. Rainbow PS. Biomonitoring of Trace Metals in Estuarine and Marine Environments. Australian J Ecotox 2006; 12: 107-122 https://doi.org/10.1016/j.chemosphere.2004.09.093

14. US EPA (2000). Environmental Protection Agency Chemical Contaminant Data for Use in Fish Advisories Vol. 1 Fish Sampling and Analysis Third Edition. Washington, DC: Office of Science and Technology.

15. Fernandes C, Fontaínhas-Fernandes A, Peixoto F, Salgado MA. Bioaccumulation of heavy metals in Liza saliens from the Esmoriz-Paramos coastal lagoon, Portugal. Ecotoxicology and Environmental Safety. 2007; 66(3):426-431 https://doi.org/10.1016/j.ecoenv.2006.02.007

16. AOAC (2005): Official Method 999.10. Lead, cadmium, zinc, copper and Iron in foods, atomic absorption spectrophotometry after microwave digestion, first action 1999. NMKL-AOAC method.

17. US EPA. Method 3052 microwave assisted acid digestion of siliceous and organically based matrices. Washington, D.C.: U.S. Environmental Protection Agency. 1996.

18. US EPA (1974). Method 206.3 Arsenic (AA, GaseousHydride). Washington, D.C.: U.S. Environmental Protection Agency.

19. Abu Hilal AH, Ismail NS. Heavy Metals in Eleven Common Species of Fish from the Gulf of Aqaba, Red Sea. Jordan J Biol Sci 2008; 1(1): 13-18

20. Younis AM, Amin HF, Alkaladi A, Mosleh YI. Bioaccumulation of heavy metals in fish, squids and crustaceans from the Red Sea, Jeddah Coast, Saudi Arabia. Open J Marine Sci 2015; 5: 369-378 https://doi.org/10.4236/ojms.2015.54030

21. Chen MH, Chen CY. Bioaccumulation of sediment-Bound Heavy Metal in grey Mullet, Liza macrolepis. Marine Pollution Bull 1999; 39(1):239- 244. https://doi.org/10.1016/S0025-326X(99)00027-2

22. Chen CY, Chen HM. Heavy metal concentrations in nine species in fishes caught in coastal waters off Ann- Ping, S. W. Taiwan. J Food Drug Ana 2001; 9:107- 114

23. Krishnamurti AJ, Nair VR. Concentration of metals in fishes from Thane and Bassein creeks of Bombay, India. Indian $\mathrm{J}$ Mar Sci 1999, 28:39-44.

24. Haung WB. Heavy Metal Concentrations in the Common Benthic Fishes Caught from the Coastal Waters of Eastern Taiwan. J Food Drug Anal 2003; 11(4): 324-330 https://doi.org/10.4194/1303-2712-v12_2_24
25. Yilmaz AB. Comparison of Heavy Metal Levels of Grey Mullet (Mugilcephalus L.) and Sea Bream (Sparusaurata L.) Caught in Iskenderun Bay (Turkey). Turk J Vet Anim Sci 2005; 29: 257-262

26. Has-Schon E, Bogut I, Strelec I. Heavy metal profile in five fish species included in human diet, Domiciled in the end flow of river Neretva (Croatia). Arch Environ Contam Toxicol 2006; 50: 545-551.https://doi.org/10.1007/s00244-005-0047-2

27. Yilmaz F, Ozdemir N, Demirak A, Levent Tuna A. Heavy metal levels in two fish species Leuciscuscephalus and Lepomisgibbosus. Food Chem 2007; 100(2):830-835. https://doi.org/10.1016/j.foodchem.2005.09.020 0

28. Ismail NS, Abu-Hilal A. Studied the heavy metals in three commonly available coral reef fish species from the Jordan Gulf of Aqaba, Red Sea. Jordan J Biol Sci 2008; 1(2): 61 - 66.

29. Tepe Y, Turkmen M, Turkmen A. Assessment of heavy metals in two commercial fish species of four Turkish seas. Environ Monit Assess 2008; 146: 277-284 https://doi.org/10.1007\%2Fs10661-007-0079-3

30. Turkmen A, Tepe Y, Turkmen M. Metal Levels in Tissues of the European Anchovy, Engrauli sencrasicolus L., 1758, and Picarel, Spicarasmaris L., 1758, from Black, Marmara and Aegean Seas. Bull Environ Contam Toxicol 2008, 521-525

31. Carpene E, Vasak M. Hepatic Metallothionein from Goldfish (Carassiusauratus). Comp Biochem Physiol. 1989; 92B:463468.https://doi.org/10.1016/0305-0491(89)90117-X

32. Ikem A, Egiebor NO, Nyavor K. Trace elements in water, fish and sediment from Tuskegee lake, Southeastern USA. Water, Air, and Soil Pollution. 2003; 149: 51-75 https://doi.org/10.1023/A:1025694315763

33. Legorburu I, Canton L, Millan E and Casado A. Trace metal levels in fish from Unda river (Spain) Anguillidae, Mugillidae and Salmonidae. Environ Technol Lett 1988; 9: 1373-1378. https://doi.org/10.1007\%2Fs10661-007-0005-8

34. Khaled A. Heavy metals concentrations in certain tissues of fivecommercially important fishes from El-Mex Bay, Alexandria, Egypt. Egyptian J Aquatic Biol Fish 2004; 8(1): 51-64.https://doi.org/10.1016/j.ejbas.2014.06.001

35. Ali AA, Elazein EM, Alian MA. Determination of Heavy Metals in Four Common Fish, Water and Sediment Collected from Red Sea at Jeddah Isalmic Port Coast. J Appl Environ Biol Sci 2011; 1(10):453-459.https://doi.org/10.1007/s11270

36. Ali AA, Elazein EM, Alian MA. Investigation of heavy metals pollution in water, sediment and fish at red sea- jeddah coastksa at two different locations, J Applied Environ Biol Sci 2011; 1(12):630-637

37. Huang BW. Heavy metal concentrations in the common benthic fishes caught from the coastal waters of Eastern Taiwan. J Food Drug Anal 2003; 11:324-330. https://doi.org/10.4194/1303-2712-v12 224

38. Kojadinovic J, Potier M, Corre ML, Cosson RP, Bustamante P. Bioaccumulation of trace elements in pelagic Fish from the Western Indian Ocean. Environ- mental Pollution, Elsevier. 2007; 146 (2):548-566

https://doi.org/10.1016/j.envpol.2006.07.015

39. Chen MH. Baseline metal concentration in sediments and fish and the determination of bio indicators in the subtropical. Baseline. Marine Poll Bull 2002, 44 (7): 703-714.

40. Tam NFY, Wong, W.S. Spatial variation of heavy metals in surface sediments of Hong Kong mangrove swamps. Environmental Poll 2000; 110:195-205. https://doi.org/10.1016/S0269-7491(99)00310-3

41. Bahnasawy M, Khidr A, Dheina, N. Seasonal Variations of Heavy Metals Concentrations in Mullet, Mugil Cephalus and Liza Ramada (Mugilidae) from Lake Manzala, Egypt. J Applied Sci Res 2009; 5:845-852.

42. FAO/ WHO, 2004. Summary of Evaluations Performed by the Joint FAO/WHO Expert Committee on Food Additives (JECFA 1956-2003), ILSI Press International Life Sciences Institute, 2004.

43. Yemen Standardization, Metrology and Quality Control. Fish and fish products, fresh fish. The Republic of Yemen 2006; 1577:1-9. 